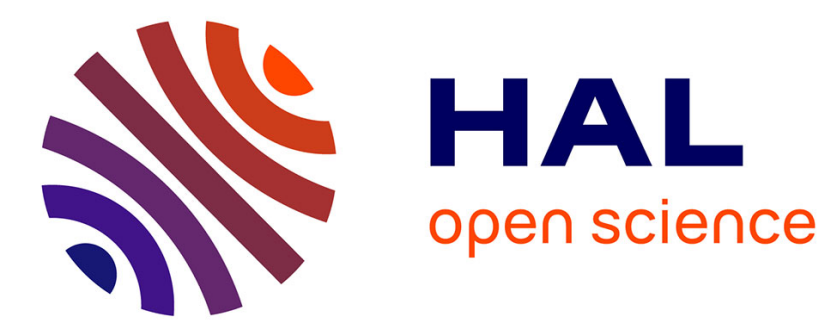

\title{
A barium germanium 1,2-ethanediolato complex as precursor for barium metagermanate
}

Roberto Köferstein, Lothar Jäger, Mandy Zenkner, Hans-Peter Abicht

\section{To cite this version:}

Roberto Köferstein, Lothar Jäger, Mandy Zenkner, Hans-Peter Abicht. A barium germanium 1,2ethanediolato complex as precursor for barium metagermanate. Thermochimica Acta, 2007, 457 (1-2), pp.55-63. 10.1016/j.tca.2007.02.021 . hal-02004738

\section{HAL Id: hal-02004738 \\ https://hal.science/hal-02004738}

Submitted on 2 Feb 2019

HAL is a multi-disciplinary open access archive for the deposit and dissemination of scientific research documents, whether they are published or not. The documents may come from teaching and research institutions in France or abroad, or from public or private research centers.
L'archive ouverte pluridisciplinaire HAL, est destinée au dépôt et à la diffusion de documents scientifiques de niveau recherche, publiés ou non, émanant des établissements d'enseignement et de recherche français ou étrangers, des laboratoires publics ou privés. 


\title{
Thermochimica Acta 457 (2007) 55-63 \\ (doi:10.1016/j.tca.2007.02.021)
}

http://dx.doi.org/10.1016/j.tca.2007.02.021

\section{A barium germanium 1,2-ethanediolato complex as precursor for barium metagermanate}

\author{
Roberto Köferstein, Lothar Jäger, Mandy Zenkner, Hans-Peter Abicht* \\ ${ }^{a}$ Fachbereich Chemie, Martin-Luther-Universität Halle-Wittenberg, \\ Kurt-Mothes Str. 2, D-06120 Halle, Germany
}

\footnotetext{
* Corresponding author. Tel.: +49-345-5525622; fax: +49-345-5527028.

E-mail address: hans-peter.abicht@chemie.uni-halle.de
}

\begin{abstract}
The thermal behaviour of $\left[\mathrm{Ba}\left(\mathrm{HOC}_{2} \mathrm{H}_{4} \mathrm{OH}\right)_{2} \mathrm{Ge}\left(\mathrm{OC}_{2} \mathrm{H}_{4} \mathrm{O}\right)_{3}\right](2)$ as a $\mathrm{BaGeO}_{3}$ precursor, and its phase evolution during thermal decomposition in different atmospheres are described herein. The precursor complex decomposes in air to a finely divided mixture of $\mathrm{BaCO}_{3}$ and $\mathrm{GeO}_{2}$, which subsequently reacts above $650{ }^{\circ} \mathrm{C}$ to orthorhombic $\mathrm{BaGeO}_{3}$, transforming above $800{ }^{\circ} \mathrm{C}$ to hexagonal $\mathrm{BaGeO}_{3}$. The shrinkage behaviour of $\mathrm{BaGeO}_{3}$ compacts made from the as-prepared powders as well as from conventional mixed-oxide powders has been investigated. The samples were characterised by Fourier transformed infrared spectroscopy (FT-IR), X-ray powder diffraction (XRD), dilatometric measurements and thermoanalytic investigations (TG/DTA).
\end{abstract}

Keywords: barium metagermanate; 1,2-ethanediolato complex of germanium; thermal decomposition; phase evolution; ceramics; shrinkage behaviour

\section{Introduction}

Germanates have found important applications in material science and technology due to their dielectric, optical as well as acoustic-optical properties $[1,2,3,4] . \mathrm{M}^{\mathrm{II}} \mathrm{GeO}_{3}$ ceramics with divalent metal ions such as $\mathrm{Ba}^{2+}, \mathrm{Sr}^{2+}, \mathrm{Ca}^{2+}, \mathrm{Ni}^{2+}$ or $\mathrm{Cu}^{2+}$ are used on an industrial scale [5]. In particular, the 
addition of germanates, such as lead germanate, to barium titanate leads to a decrease in the sintering temperature and thus allows the production of heterophasic ceramic bodies of high electric strength and low dissipation factor [6]. $\mathrm{BaGeO}_{3}$ exists in two polymorphic forms. Hexagonal $(\alpha)$ $\mathrm{BaGeO}_{3}$ (low-temperature form) has a pseudowollastonite-type structure in which the $\mathrm{GeO}_{4}$ tetrahedra are linked to 3-membered $\left[\mathrm{Ge}_{3} \mathrm{O}_{9}\right]$-rings [7], whereas orthorhombic $(\beta)-\mathrm{BaGeO}_{3}$ (hightemperature form) has a pyroxene-type structure, containing $\mathrm{GeO}_{4}$ tetrahedra which are linked to 2periodic chains [8]. The phase diagram of the $\mathrm{BaO}-\mathrm{GeO}_{2}$ system was published by Guha [9] and shows the reversible hexagonal $\leftrightarrows$ orthorhombic transformation at $1200{ }^{\circ} \mathrm{C}$ and a melting point at $1280{ }^{\circ} \mathrm{C}$. Moreover, Guha et al. [10] observed that the high-temperature form can be retained at room temperature, depending on the cooling rate.

Usually, preparation of $\mathrm{BaGeO}_{3}$ powder bases by the conventional mixed-oxide method, through the reaction of $\mathrm{BaCO}_{3}$ with $\mathrm{GeO}_{2}$, requires temperatures of about $1100{ }^{\circ} \mathrm{C}[10,11]$. Yamaguchi et al. [12] briefly reported the simultaneous hydrolysis of a mixture of barium- and germanium alkoxides and subsequent decomposition to $\mathrm{BaGeO}_{3}$. The decomposition leads directly to the formation of orthorhombic $\mathrm{BaGeO}_{3}$ below $1000{ }^{\circ} \mathrm{C}$. In ref. [13] we reported the crystal structure of the precursor complex $\left[\mathrm{Ba}\left(\mathrm{HOC}_{2} \mathrm{H}_{4} \mathrm{OH}\right)_{2} \mathrm{Ge}\left(\mathrm{OC}_{2} \mathrm{H}_{4} \mathrm{O}\right)_{3}\right] \cdot 1.25 \mathrm{HOC}_{2} \mathrm{H}_{4} \mathrm{OH}(\mathbf{1})$. This complex forms a ribbon-like polymeric structure. Briefly, $\mathrm{Ba}^{2+}$ is coordinated to nine oxygen atoms stemming from 1,2ethanediol molecules, whereas $\mathrm{Ge}^{4+}$ is coordinated to three 1,2-ethanediolat anions $(\mathrm{c} . n .=6)$. The oxygen atoms of the ligands also act as bridging atoms between the coordination polyhedra. As a result of the bridging function, rings are formed containing two $\left[\mathrm{Ba}\left(\mathrm{HOC}_{2} \mathrm{H}_{4} \mathrm{OH}\right)_{2} \mathrm{Ge}\left(\mathrm{OC}_{2} \mathrm{H}_{4} \mathrm{O}\right)_{3}\right]$ units. These rings are also bridged by 1,2-ethanediol molecules forming infinite ribbons. Uncoordinated 1,2-ethanediol molecules are situated between the ribbons. Even below $1000{ }^{\circ} \mathrm{C}$ decoposition of 1 to $\mathrm{BaGeO}_{3}$ occurs. Because of the relatively low calcination temperature this method supplies preceramic powders with higher sintering activity than powders fabricated by the mixed-oxide method. We are interested in the use of $\mathrm{BaGeO}_{3}$ as a sintering additive to reduce the sintering temperature for $\mathrm{BaTiO}_{3}$ ceramics, with a view to producing nano-granular ceramics. The $\mathrm{BaGeO}_{3}-\mathrm{BaTiO}_{3}$ system, prepared by the conventional mixed-oxide method, was studied only by Guha and Kolar [14]. Here we describe in detail the phase evolution during thermal decomposition, in different atmospheres, of $\left[\mathrm{Ba}\left(\mathrm{HOC}_{2} \mathrm{H}_{4} \mathrm{OH}\right)_{2} \mathrm{Ge}\left(\mathrm{OC}_{2} \mathrm{H}_{4} \mathrm{O}\right)_{3}\right]$ (2) yielding finally $\mathrm{BaGeO}_{3}$. In addition, the shrinkage and sintering behaviour of powder compacts have also been investigated.

\section{Experimental}

\subsection{Material preparation}

In a previous paper we have described the preparation procedure for $\mathbf{1}$ and $\mathbf{2}$ starting from wet $\mathrm{GeO}_{2}$ - $n \mathrm{H}_{2} \mathrm{O}$ with $\mathrm{Ba}(\mathrm{OH})_{2} \cdot 8 \mathrm{H}_{2} \mathrm{O}$ in boiling 1,2-ethanediol [13]. However, in this work we used a 
modified method: germanium(IV) ethoxide (0.1 mol, Alfa Aesar GmbH \& Co KG, Germany) and $\mathrm{Ba}(\mathrm{OH})_{2} \cdot 8 \mathrm{H}_{2} \mathrm{O}(0.1 \mathrm{~mol}$, Fluka Chemie $\mathrm{GmbH}$, Switzerland) were dissolved in $1000 \mathrm{ml}$ of boiling 1,2-ethanediol. After reflux for $24 \mathrm{~h}, 2 / 3$ of the solvent was first removed under normal pressure and about $200 \mathrm{ml}$ was then removed under reduced pressure at $100{ }^{\circ} \mathrm{C}$. The reaction mixture was cooled and diluted with $100 \mathrm{ml}$ of acetone. The resulting white crystalline precipitate of 2 was filtered off and washed with acetone (slow cooling also led to 1 in accordance with [13]). Yield: 65 $\%$.

Analysis: $\mathrm{C}_{10} \mathrm{H}_{24} \mathrm{O}_{10} \mathrm{BaGe}(514.23 \mathrm{~g} / \mathrm{mol})$ : calc. C, $23.36 \%$; $4.70 \%$, found $\mathrm{C}, 23.51 \% ; \mathrm{H}, 4.81$ $\%$.

$\mathrm{X}$-ray fluorescence analysis indicated a $\mathrm{Ba} / \mathrm{Ge}$ atomic ratio of $1.007: 1$.

The phase evolution during the thermal decomposition of $\mathbf{2}$ was studied on samples which were heated up to $1050{ }^{\circ} \mathrm{C}$ (rate: $10 \mathrm{~K} / \mathrm{min}$ ) in a Pt-crucible in a static air or flowing oxygen atmosphere. The sample for shrinkage behaviour was calcined at $800{ }^{\circ} \mathrm{C}$ for $2 \mathrm{~h}$ in static air. In a teflon container, the resulting white powder (2a) was milled for $2 \mathrm{~h}$ using $\mathrm{ZrO}_{2}$ balls in 2-propanol $\left(\mathrm{m}_{\text {powder }}: \mathrm{m}_{\text {balls }}=1: 4\right)$. After filtering and drying the powder was mixed with 5 mass $\%$ of a saturated aqueous solution of polyvinyl alcohol as a pressing aid. The powder was pressed to discs with a green density of about $2.6 \mathrm{~g} / \mathrm{cm}^{3}$. For comparative purposes, barium metagermanate powder (3) was also prepared by the conventional mixed-oxide method. For this peparation, $\mathrm{BaCO}_{3}$ (Merck 1713, extra pure, Merck, Germany) and $\mathrm{GeO}_{2}$ (99.998\%, Sigma-Aldrich Chemie GmbH, Germany) were milled in a molar ratio of 1:1 for $24 \mathrm{~h}$ in a PVC container with the addition of distilled water and agate balls $\left(\mathrm{m}_{\text {powder }}: \mathrm{m}_{\text {balls }}: \mathrm{m}_{\text {water }}=1: 1: 4\right)$. After filtering off and drying, the batch was calcined in static air at $1150{ }^{\circ} \mathrm{C}$ for $2 \mathrm{~h}$ to give a white powder. The remaining steps are identical to those mentioned above (as for $\mathbf{2 a}$ ). All observed crystalline phases were stable at room temperature.

\subsection{Analytical methods}

The infrared spectra were recorded on FTIR spectrometer Mattson 5000 (Mattson Instruments Inc., USA) at $25{ }^{\circ} \mathrm{C}$ in the range of $350-4000 \mathrm{~cm}^{-1}$ with a resolution of $2 \mathrm{~cm}^{-1}$ as $\mathrm{KBr}$ pellets. X-ray powder diffraction (XRD) patterns were recorded by a STADI MP diffractometer (STOE, Germany) at $25{ }^{\circ} \mathrm{C}$ with the following equipment: transmission / Debye-Scherrer geometry, curved imaging plate detector, curved crystal germanium monochromator, $\mathrm{CoK} \alpha_{1}$ radiation (1.78896 ^), and a step size of $0.03^{\circ}$ for $2 \theta$. Simultaneous thermogravimetric (TG) and differential thermoanalytic (DTA) measurements in different atmospheres were achieved using a STA 449C (Netzsch, Germany, Pt crucible, heating rate $10 \mathrm{~K} / \mathrm{min}$, flow rate $20 \mathrm{ml} / \mathrm{min}$ ). The dilatometric investigations (shrinkage) were performed in a TMA 92-16.18 unit (Setaram, France, flowing air atmosphere, temperature rate $10 \mathrm{~K} / \mathrm{min}$ and $5 \mathrm{~min}$ dwelling time at the highest temperature). The 
densities of the discs were calculated assuming an isotropic shrinkage behaviour. The specific surface area was measured using nitrogen three-point BET (Nova 1000, Quantachrome Corporation, USA). Measurements of the dielectric constants at 1 and $10 \mathrm{kHz}$ were achieved using an Impedance Analyzer 4192 Alf (Hewlett Packard, USA) and a temperature rate of $0.5 \mathrm{~K} / \mathrm{min}$. An analyser CHNS 932 (LECO Instruments $\mathrm{GmbH}$ ) was used for elemental analyses. Scanning electron microscope images were recorded with a Philips XL30 ESEM (Environmental Scanning Electron Microscope).

\section{Results and discussion}

\subsection{Thermal behaviour of 2}

Fig. 1 and 2 show the TG and DTA curves up to $1000{ }^{\circ} \mathrm{C}$ for $\left[\mathrm{Ba}\left(\mathrm{HOC}_{2} \mathrm{H}_{4} \mathrm{OH}\right)_{2} \mathrm{Ge}\left(\mathrm{OC}_{2} \mathrm{H}_{4} \mathrm{O}\right)_{3}\right]$ (2) in flowing air, oxygen and argon atmospheres, as well as under vacuum.

TG/DTA investigation in flowing air shows the beginning of an exothermic reaction at $157^{\circ} \mathrm{C}$. The corresponding weight loss of $22.8 \%$ differs a little from the calculated weight loss for two 1,2ethanediol molecules per formula $(24.2 \%)$. The loss of solvate molecules should be endothermic, but the loss of these 1,2-ethanediol molecules is accompanied by their decomposition. The splittingoff of the solvate molecules allows their decomposition to hydrocarbon fragments [15], which react with atmospheric oxygen to form $\mathrm{CO}_{2}$ and $\mathrm{H}_{2} \mathrm{O}$ on the surfaces of particles. This exothermic reaction overlaps the endothermic one $[16,17]$. The desolvated compound is not stable. Several weight losses follow up to $564{ }^{\circ} \mathrm{C}$ leading to a total weight loss of $40.4 \%$. Two exothermic peaks with onset temperatures of $232{ }^{\circ} \mathrm{C}$ and $479{ }^{\circ} \mathrm{C}$ can be observed. This state represents the complete transformation of 2 to a mixture of $\mathrm{BaCO}_{3}$ and $\mathrm{GeO}_{2}$ (calc. $41.3 \%$ ). A two-step weight loss between 653 and $730{ }^{\circ} \mathrm{C}$ leads to the formation of $\mathrm{BaGeO}_{3}$. During this process two exothermic peaks, with onset temperatures of 653 and $678{ }^{\circ} \mathrm{C}$ can be observed. The total weight loss amounts to $50.5 \%$ (calc. $49.8 \%$ ). The XRD measurement of the final white product $\left(1000{ }^{\circ} \mathrm{C}\right)$ indicates hexagonal $\mathrm{BaGeO}_{3}$ and traces of $\mathrm{Ba}_{2} \mathrm{GeO}_{4}$ [18] (Fig. 3a). The transformation of 2 to $\mathrm{BaGeO}_{3}$ is, with a heating rate of $1 \mathrm{~K} / \mathrm{min}$, complete at $700{ }^{\circ} \mathrm{C}$.

The TG curve of $\mathbf{2}$ in an oxygen atmosphere is similar to the TG curve in air. They differ only in the final stage, which begins at $650{ }^{\circ} \mathrm{C}$, leads to a gradual weight loss and is only finished at $827{ }^{\circ} \mathrm{C}$. The total weight loss of $47.8 \%$ differs from the calculated value (49.8\%). A XRD investigation shows that the final white product $\left(1000{ }^{\circ} \mathrm{C}\right)$ consists of hexagonal $\mathrm{BaGeO}_{3}$ and small amounts of $\mathrm{Ba}_{2} \mathrm{GeO}_{4}$ (Fig. 3b). However, the DTA investigation differs slightly from the investigation in air. The DTA curve shows two strong exothermic peaks with onset temperatures at 161 and $207{ }^{\circ} \mathrm{C}$. Between about 340 and $520{ }^{\circ} \mathrm{C}$ two weak exothermic peaks can be observed. A final single strong exothermic peak appears at an onset temperature of $643{ }^{\circ} \mathrm{C}$. 
Unlike the behaviour observed in oxygen and air, the TG/DTA measurement under argon shows a broad endothermic peak between about $113-226{ }^{\circ} \mathrm{C}$. The weight loss up to $264{ }^{\circ} \mathrm{C}$ is $22.4 \%$ and corresponds with the loss of the solvate molecules. This is followed by a gradual weight loss until about $501{ }^{\circ} \mathrm{C}$ and is consistent with the formation of $\mathrm{BaCO}_{3}$ and $\mathrm{GeO}_{2}$ (total weight loss $41.4 \%$ ). A slight weight loss, starting at $717{ }^{\circ} \mathrm{C}$, indicates the formation of orthorhombic $\mathrm{BaGeO}_{3}$. The XRD diagram of a TG/DTA sample heated up to $850{ }^{\circ} \mathrm{C}$ (black coloured powder) mainly shows reflexions of orthorhombic $\mathrm{BaGeO}_{3}$ and $\mathrm{Ba}_{2} \mathrm{GeO}_{4}$ (Fig. 3c). A final weight loss beginning at 876 ${ }^{\circ} \mathrm{C}$, as a result of an endothermic process, continues up to $1000^{\circ} \mathrm{C}$ to give a total weight loss of 52.0 $\%$. The final product at $1000{ }^{\circ} \mathrm{C}$ (grey coloured) consists of $\mathrm{Ba}_{2} \mathrm{GeO}_{4}$ and small amounts of orthorhombic $\mathrm{BaGeO}_{3}$ (Fig. 3d). However, we cannot confirm any traces of $\mathrm{BaGe}_{4} \mathrm{O}_{9}$ formed by reaction of $\mathrm{BaCO}_{3}$ and $\mathrm{GeO}_{2}$ in a $\mathrm{CO}_{2}$ atmosphere, as described by Kuno et al. [19]. The black-grey colour of the product arises from elemental carbon; an elemental analysis shows a carbon content of about 5 mass \%. In contrast to the thermolysis in air and oxygen, 2 decomposes to $\mathrm{BaCO}_{3}$ and $\mathrm{GeO}_{2}$ reacting above $717{ }^{\circ} \mathrm{C}$ to form orthorhombic $\mathrm{BaGeO}_{3}$ which decomposes to $\mathrm{Ba}_{2} \mathrm{GeO}_{4}$ with increasing temperature. The formation of $\mathrm{Ba}_{2} \mathrm{GeO}_{4}$ from $\mathrm{BaGeO}_{3}$ is in principal possible in two ways. $\mathrm{BaGeO}_{3}$ decomposes to $\mathrm{Ba}_{2} \mathrm{GeO}_{4}$ and $\mathrm{GeO}_{2}$ (analogous to $\mathrm{FeGeO}_{3}$ [20]) or to $\mathrm{Ba}_{2} \mathrm{GeO}_{4}$ and elemental Ge under reducing conditions, as described by Royen at al. [21]. The exclusion of oxygen and the presence of elemental carbon can lead to reducing conditions at high temperatures. A very weak reflexion at $2 \theta=31.8^{\circ}$ in Fig. $3 \mathrm{~d}$ possibly hints at the formation of small amounts of elemental Ge [18], but the signal-to-noise ratio is poor. Neither XRD nor IR investigations indicate the formation of other reduced compounds such as $\mathrm{GeO}$ [22]. The calculated weight loss of $52.9 \%$ for the formation of $\mathrm{Ba}_{2} \mathrm{GeO}_{4}$ and Ge differs only slightly from the observed value of $52.0 \%$.

The DTA investigation under vacuum shows two endothermic peaks between 114-171 and 171-198 ${ }^{\circ} \mathrm{C}$ as well as a broad endothermic peak between 225 and $283{ }^{\circ} \mathrm{C}$. These endothermic processes cause a weight loss of $22.1 \%$. This is followed by a weight loss up to about $523{ }^{\circ} \mathrm{C}$ which leads to a very poor crystalline phase consisting of both orthorhombic $\mathrm{BaCO}_{3}$ and hexagonal $\mathrm{GeO}_{2}$ [18] (Fig. 3e). Between 679-1000 ${ }^{\circ} \mathrm{C}$ a two-step weight loss that results in the a total weight loss of $47.6 \%$ is accompanied by two exothermic processes at $722-811^{\circ} \mathrm{C}$ and $811-891{ }^{\circ} \mathrm{C}$, respectively. The XRD diagrams of black coloured products at $840{ }^{\circ} \mathrm{C}$ and $1000{ }^{\circ} \mathrm{C}$ exclusively indicate reflexions of $\mathrm{Ba}_{2} \mathrm{GeO}_{4}$ (Fig. 3f,g). In contrast to the thermal behaviour under argon, $\mathrm{Ba}_{2} \mathrm{GeO}_{4}$ is formed directly by the reaction between $\mathrm{BaCO}_{3}$ and $\mathrm{GeO}_{2}$.

The development of the specific surface area of $\mathbf{2}$ and its dependence on the calcination temperature is shown in Fig. 4. The small increase in specific surface area up to $200{ }^{\circ} \mathrm{C}$ suggests no major structural changes during the loss of the 1,2-ethanediol molecules. Further decomposition up to about $400{ }^{\circ} \mathrm{C}$ leads to an increase in specific surface area. The increasing specific surface area is not 
only caused by the evolution of consecutive gaseous products, but also by the different densities, and hence the molar volumes of $\mathbf{2}\left(\rho \approx 2 \mathrm{~g} / \mathrm{cm}^{3}\right)$ and the formed compounds $\mathrm{BaCO}_{3}$ and $\mathrm{GeO}_{2}(\rho \approx$ $4 \mathrm{~g} / \mathrm{cm}^{3}$ ). The different densities lead to strains within the crystallites during the transformation, so that these crystallites collapse into a very large number of particles [23,24,25]. At about $600{ }^{\circ} \mathrm{C}$ the specific surface area fell to a minimum, although the TG curve in air shows several mass losses in this temperature range. The process of decomposition resulting in a larger specific surface area is compensated by a sintering-like process (Ostwald ripening). A further increase in specific surface area between $600-700{ }^{\circ} \mathrm{C}$ is caused by the reaction between $\mathrm{BaCO}_{3}$ and $\mathrm{GeO}_{2}$ to form $\mathrm{BaGeO}_{3}$. As opposed to this behaviour, a decreasing specific surface area can be observed above $700{ }^{\circ} \mathrm{C}$. The process between 700 and $900{ }^{\circ} \mathrm{C}$ corresponds to the Tammann number of $\alpha=0.64-0.75$, and therefore the sintering process can be explained as a lattice diffusion $[26,27,28]$.

The particles of 2 exhibit a slab-like morphology (Fig. 5a). During the calcination process the resulting powders consist of slabs and broad staffs in different sizes (Fig. 5b). However, these particles show an additional microstructure consisting of globular grains, the grain size depending on the calcination temperature. A calcination temperature of $750{ }^{\circ} \mathrm{C}$ leads to a grain size of about 100-250 nm (Fig. 5c), whereas a temperature of $1000{ }^{\circ} \mathrm{C}$ leads to an enormous grain growth with grain sizes of about $1-3 \mu \mathrm{m}$.

\subsection{X-ray powder diffraction (XRD) and IR spectroscopic investigation of 2}

The IR spectrum of 2 (Fig. 6a) reveals O-H stretching vibrations between about $3500-3000 \mathrm{~cm}^{-1}$ and $\mathrm{C}-\mathrm{H}$ stretching vibrations between $2950-2800 \mathrm{~cm}^{-1}$ (not shown in Fig. 6). A broad peak at about $1645 \mathrm{~cm}^{-1}$ is primarily due to water adsorbed by $\mathrm{KBr}$. Between $1500-1200 \mathrm{~cm}^{-1}$ absorption bands for $\mathrm{CH}_{2}$ deformation vibrations can be observed (always coupled with a $\mathrm{C}-\mathrm{O}-\mathrm{H}$ deformation mode): $1459 \mathrm{~cm}^{-1}$ (bending mode), $1344 \mathrm{~cm}^{-1}$ (wagging mode), 1236 and $1212 \mathrm{~cm}^{-1}$ (twisting modes, coupled with the wagging mode) [29,30,31]. The $\mathrm{C}-\mathrm{O}$ stretching vibration is chiefly observed as a strong band at $1063 \mathrm{~cm}^{-1}$ with a shoulder at $1088 \mathrm{~cm}^{-1}$. The band at $902 \mathrm{~cm}^{-1}$ with a weak shoulder at $877 \mathrm{~cm}^{-1}$ (inset in Fig. 6b) is assigned to the $\mathrm{CH}_{2}$ rocking mode [29,31]. Normalcoordinate calculations have suggested mode mixing among the $\mathrm{C}-\mathrm{O}-\mathrm{C}-\mathrm{C}$ stretching and $\mathrm{CH}_{2}$ rocking vibrations in the gauche conformation of 1,2-ethanediol [32,33]. Therefore, the $\mathrm{C}-\mathrm{O}$ stretching and $\mathrm{CH}_{2}$ rocking bands indicate that the 1,2-ethanediol molecules and 1,2-ethanediolate anions form a gauche-like conformation [34]. A comparison with 1 [13] supports this conclusion. $\mathrm{Ge}-\mathrm{O}$ vibrations are mainly manifested at $621,579,487$ and $417 \mathrm{~cm}^{-1}$ (typical of $\mathrm{GeO}_{6}$ octahedrons $[35,36,37])$. 
The XRD pattern of 2 (Fig. 7a) shows a well-developed crystalline state of the powder in accordance with the results in [13].

\subsection{Phase evolution during the thermal decomposition of 2}

\subsubsection{IR spectroscopy}

The IR spectrum (Fig. 6) of a sample calcined at $200{ }^{\circ} \mathrm{C}$ does not show any changes in comparison with the IR spectrum of 2 . Calcinating up to $300{ }^{\circ} \mathrm{C}$ reveals bands belonging to the barium germanium(IV) precursor, new bands at about 1420 and $856 \mathrm{~cm}^{-1}$ announcing the formation of $\mathrm{BaCO}_{3}$ and a strong band at $1566 \mathrm{~cm}^{-1}$, which probably indicates the formation of carboxylate groups. A number of the alkoxide groups of the precursor are possibly oxidized to - $\mathrm{COO}^{-}$groups during calcination. Heating up to $400{ }^{\circ} \mathrm{C}$ results in the disappearance of the band at $1057 \mathrm{~cm}^{-1}$ and an increase in the broad $\mathrm{BaCO}_{3}$ band. The appearance of a strong new peak at $1621 \mathrm{~cm}^{-1}$ indicates the formation of bridging $\mathrm{O}-\mathrm{H}$ groups, which can also be observed during the thermolysis of other metal alkoxides $[38,39]$. This band becomes weaker with increasing temperature. The formation of $\mathrm{GeO}_{2}\left(\mathrm{GeO}_{4}\right.$ tetrahedra $)$ is indicated by broad bands at about $793-770 \mathrm{~cm}^{-1}$ and $580 \mathrm{~cm}^{-1}$ [37]. After calcination at $700{ }^{\circ} \mathrm{C}$ bands in the range of $800-490 \mathrm{~cm}^{-1}$ indicate the initial formation of orthorhombic $\mathrm{BaGeO}_{3}$. Calcination at $800{ }^{\circ} \mathrm{C}$ reveals the typical IR pattern for germanate with a pyroxene structure, and thus the formation of orthorhombic $\mathrm{BaGeO}_{3}$ [40]. The bands were assigned as follows: GeOGe anti-symmetric stretching vibration (the oxygen atom is bridging between two $\mathrm{GeO}_{4}$ tetrahedra) at $794 \mathrm{~cm}^{-1}$ and ${ }^{-} \mathrm{OGeO}^{-}$anti-symmetric and symmetric stretching vibrations (the oxygen atoms are terminal ones of $\mathrm{GeO}_{4}$ tetrahedron) at 754 and $717 \mathrm{~cm}^{-1}$, respectively. The appearance of two bands at 583 and $497 \mathrm{~cm}^{-1}$, representing the GeOGe symmetric stretching modes, is characteristic of $\left[\mathrm{Ge}_{2} \mathrm{O}_{6}\right]_{\infty}$ 2-periodic chains [41,42]. The peak at $1425 \mathrm{~cm}^{-1}$ represents the remaining $\mathrm{BaCO}_{3}$. Heat treatment at $900{ }^{\circ} \mathrm{C}$ and higher for $1 \mathrm{~h}$ leads to typical infrared bands for hexagonal $\mathrm{BaGeO}_{3}$ with the following assignments: anti-symmetric and symmetric ${ }^{-} \mathrm{OGeO}^{-}$ stretching modes at $841 \mathrm{~cm}^{-1}$ (shoulder at $816 \mathrm{~cm}^{-1}$ ), GeOGe stretching vibrations $\left(v_{\mathrm{as}}\right.$ and $\left.v_{\mathrm{s}}\right)$ at 743 and $488 \mathrm{~cm}^{-1}$ and ${ }^{-} \mathrm{OGeO}^{-}$in-plane rocking vibration at $401 \mathrm{~cm}^{-1}$ [43]. The appearance of a band at $488 \mathrm{~cm}^{-1}$ and the absence of the aforementioned peak at $583 \mathrm{~cm}^{-1}$ is characteristic of the formation of a 3-membered $\left[\mathrm{Ge}_{3} \mathrm{O}_{9}\right]$-ring $[41,44]$.

\subsubsection{XRD measurements}

Phase evolution during the thermal decomposition of $\mathbf{2}$ was studied on samples by heating in a muffle furnace up to a certain temperature (rate $10 \mathrm{~K} / \mathrm{min}$ ), dwelling at this temperature and then cooling down to room temperature. 
Fig. 7 shows XRD diagrams of samples heated up to $1000{ }^{\circ} \mathrm{C}$ in static air. Analogous to the IR investigations, it is only after heat treatment to $300{ }^{\circ} \mathrm{C}$ for $1 \mathrm{~h}$ that decomposition of 2 appears to begin. The broad reflexions in the range up to $2 \theta \approx 15^{\circ}$ can be assigned to residues of the precursor complex. The formation of $\mathrm{BaCO}_{3}$ and hexagonal $\mathrm{GeO}_{2}$ can also be observed. Only at a temperature of $400{ }^{\circ} \mathrm{C}$ does complete decomposition of 2 to $\mathrm{BaCO}_{3}$ and hexagonal $\mathrm{GeO}_{2}$ occur. Orthorhombic $\mathrm{BaGeO}_{3}$ appears above a calcination temperature of $650{ }^{\circ} \mathrm{C}$. Elevation of the temperature to $700{ }^{\circ} \mathrm{C}$ results in an increase of orthorhombic $\mathrm{BaGeO}_{3}$ content and a decrease in $\mathrm{BaCO}_{3}$ and $\mathrm{GeO}_{2}$, so that reflexions of $\mathrm{BaCO}_{3}$ and $\mathrm{GeO}_{2}$ disappear after a dwelling time of $10 \mathrm{~h}$. Calcination at $800{ }^{\circ} \mathrm{C}$ for $1 \mathrm{~h}$ yields orthorhombic $\mathrm{BaGeO}_{3}$. However an increase in the calcination time leads to the gradual formation of hexagonal $\mathrm{BaGeO}_{3}$. We observed a complete transformation to hexagonal $\mathrm{BaGeO}_{3}$ after more than $2 \mathrm{~h}$. The XRD pattern of a sample calcined at $900{ }^{\circ} \mathrm{C}$ for $1 \mathrm{~h}$ shows the appearance of hexagonal $\mathrm{BaGeO}_{3}$ with small amounts of orthorhombic $\mathrm{BaGeO}_{3}$. Further heating to $1000{ }^{\circ} \mathrm{C}$ resulted only in reflexions of hexagonal $\mathrm{BaGeO}_{3}$ and small traces of $\mathrm{Ba}_{2} \mathrm{GeO}_{4}$. The decomposition of 2 up to $1000{ }^{\circ} \mathrm{C}$ (dwelling time $1 \mathrm{~h}$ ) in static air can be summarized as follows:

$$
\left[\mathrm{Ba}\left(\mathrm{HOC}_{2} \mathrm{H}_{4} \mathrm{OH}\right)_{2} \mathrm{Ge}\left(\mathrm{OC}_{2} \mathrm{H}_{4} \mathrm{O}\right)_{3}\right] \underset{-\mathrm{H}_{2} \mathrm{O},-\mathrm{CO}_{2}}{\longrightarrow} \mathrm{BaCO}_{3}+\mathrm{GeO}_{2} \frac{>650{ }^{\circ} \mathrm{C}}{-\mathrm{CO}_{2}} \text { ortho. }-\mathrm{BaGeO}_{3} \stackrel{>800{ }^{\circ} \mathrm{C}}{\longrightarrow} \text { hex. }-\mathrm{BaGeO}_{3}
$$

All samples calcined in static air between $300-700{ }^{\circ} \mathrm{C}$ showed a black-grey colour, ascribed to traces of elemental carbon. It can be seen that the thermolysis of 2 leads to orthorhombic $\mathrm{BaGeO}_{3}$ at a low temperature, in contrast to the conventional synthesis [10]. Increasing calcination temperature $\left(>750{ }^{\circ} \mathrm{C}\right.$ ) and time of exposure promoted the formation of hexagonal $\mathrm{BaGeO}_{3}$. However, the infrared investigations show the presence of small amounts of unreacted $\mathrm{BaCO}_{3}$ and consequently $\mathrm{GeO}_{2}$ above $700{ }^{\circ} \mathrm{C}$. It can be observed that a decrease in the unreacted species (especially $\mathrm{GeO}_{2}$ ) leads to a gradual increase in hexagonal $\mathrm{BaGeO}_{3}$. Heat treatment of a mixture of 2 with additional amounts of hexagonal $\mathrm{GeO}_{2}$ [83-543] at $900{ }^{\circ} \mathrm{C}$ for $1 \mathrm{~h}$ clearly causes an increase in the orthorhombic $\mathrm{BaGeO}_{3}$ phase (Fig. 71). The appearance of orthorhombic $\mathrm{BaGeO}_{3}$ below $1000{ }^{\circ} \mathrm{C}$ and its stability at room temperature is promoted by the presence of unreacted $\mathrm{GeO}_{2}$ and small particle sizes. The dependence of the observed crystal structure on the particle size is also well known for $\mathrm{BaTiO}_{3}$ and $\mathrm{ZrO}_{2}[45,46]$.

Additionally, the formation of $\mathrm{BaGeO}_{3}$ up to $1000{ }^{\circ} \mathrm{C}$ is accompanied by the formation of traces of $\mathrm{Ba}_{2} \mathrm{GeO}_{4}$. Only a heat treatment of at least $1050{ }^{\circ} \mathrm{C}$ for $2 \mathrm{~h}$ leads to pure $\mathrm{BaGeO}_{3}$. Previous studies on a $\mathrm{BaO}-\mathrm{GeO}_{2}$ system by Zhmud et al. [47] and Jasim et al. [48] also described the presence of traces of $\mathrm{Ba}_{2} \mathrm{GeO}_{4}$. Analogous observations are reported for $\mathrm{FeGeO}_{3}$ [49] and alkaline-earth metasilicates [50]. Fig. 8 shows XRD patterns for 2 at a calcination temperature of $750{ }^{\circ} \mathrm{C}$ and at different dwelling times. It can be seen, that the weak reflexions of $\mathrm{Ba}_{2} \mathrm{GeO}_{4}((211),(020))$ appear 
after the formation of orthorhombic $\mathrm{BaGeO}_{3}$. After a calcination time of 1 min only reflexions of orthorhombic $\mathrm{BaGeO}_{3}$ can be observed. A prolonged dwelling time of 30 min leads to the appearance of $\mathrm{Ba}_{2} \mathrm{GeO}_{4}$ reflexions. In contrast to the formation of $\mathrm{BaGeO}_{3}$ from a conventional mixture of $\mathrm{BaCO}_{3}$ and $\mathrm{GeO}_{2}$ [21,49], we do not obtain a prior formation of $\mathrm{Ba}_{2} \mathrm{GeO}_{4}$ during the decomposition of $\mathbf{2}$. This means that $\mathbf{2}$ decomposes in air to yield a fine mixture of $\mathrm{BaCO}_{3}$ and $\mathrm{GeO}_{2}$, which reacts directly to $\mathrm{BaGeO}_{3}$. Jasim et al. [48] reported that a portion of the $\mathrm{BaGeO}_{3}$ possibly decomposed to $\mathrm{Ba}_{2} \mathrm{GeO}_{4}$ and $\mathrm{GeO}_{2}$.

Thermal decomposition in a flowing oxygen atmosphere leads, at $300{ }^{\circ} \mathrm{C}$, to the appearance of orthorhombic $\mathrm{BaGeO}_{3}$ (Fig. 9). At a heating time of 5 min reflexions of $\mathrm{Ba}_{2} \mathrm{GeO}_{4}$ can be detected. Even a prolonged heating time leads only to a slight decrease of $\mathrm{Ba}_{2} \mathrm{GeO}_{4}$. Only an increased calcination temperature reduces the $\mathrm{Ba}_{2} \mathrm{GeO}_{4}$ content. Under the conditions mentioned above, the decomposition in flowing oxygen takes place at a lower calcination temperature, but the resulting powders consist of hard agglomerates and contain higher amounts of $\mathrm{Ba}_{2} \mathrm{GeO}_{4}$ (up to $500{ }^{\circ} \mathrm{C}$ ) in contrast to decomposition in static air.

\subsection{Shrinkage and sintering behaviour}

The preceramic powders, which were used for these investigations, consisted of hexagonal $\mathrm{BaGeO}_{3}$.

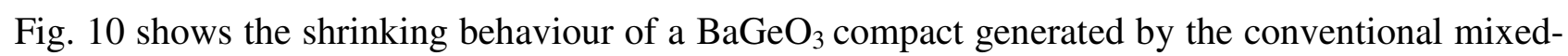
oxide reaction (3) at $1150{ }^{\circ} \mathrm{C}$ for $2 \mathrm{~h}$. The shrinkage starts at about $880{ }^{\circ} \mathrm{C}$ and the shrinkage rate reaches a maximum at $1195{ }^{\circ} \mathrm{C}$. An increase in the shrinkage up to $1213{ }^{\circ} \mathrm{C}$ can be observed. Up to about $1200{ }^{\circ} \mathrm{C}$ a phase transition takes place from the hexagonal to the orthorhombic form $[12,10]$. At the end of the heating cycle, the relative density of the sintered body is $65 \%$ with reference to orthorhombic $\mathrm{BaGeO}_{3}$. During the cooling cycle between $1096-1028{ }^{\circ} \mathrm{C}$ an expansion of the sintered body can be seen, which is caused by the reverse phase transition (orthorhombic $\rightarrow$ hexagonal), which is connected with a decrease in density on going from orthorhombic $\mathrm{BaGeO}_{3}$ $\left(5.16 \mathrm{~g} / \mathrm{cm}^{3}\right)$ to hexagonal $\mathrm{BaGeO}_{3}\left(4.77 \mathrm{~g} / \mathrm{cm}^{3}\right)$ [7,8]. Moreover the expansion process is accompanied by a densification during the sintering process, therefore the expansion is about $4 \%$ and is lower than the expected value of $8 \%$. The XRD pattern after the dilatometric measurement indicates hexagonal $\mathrm{BaGeO}_{3}$.

The shrinkage behaviour of powder compacts, which were synthesised by the complex-precursormethod (2a) are shown in Fig. 11. The sample begins to shrink at about $805{ }^{\circ} \mathrm{C}$ and an increase in the rate of shrinkage is observed above $900{ }^{\circ} \mathrm{C}$. The maximum shrinkage rate is reached at about $1174{ }^{\circ} \mathrm{C}$. It is clear that, green bodies resulting from 2a have a higher sintering activity than those of 3. The enormous increase in the expansion of the sample during the cooling stage between 1100 and $1018{ }^{\circ} \mathrm{C}$ is due the reverse phase transition, as mentioned above. The better densification during the 
heating process up to $1250{ }^{\circ} \mathrm{C}$ yields bodies with densities of $89 \%$ relative to orthorhombic $\mathrm{BaGeO}_{3}$. Therefore, the reverse phase transition during the cooling phase causes high strains within the grain structure and leads to an extensive microcracking and finally to the destruction of the sintered body. Pure $\mathrm{BaTiO}_{3}$ [51] and pure $\mathrm{ZrO}_{2}$ [52,53] show an analogous behaviour. The crystalline phase detected after the cooling process was hexagonal $\mathrm{BaGeO}_{3}$. However, heating up to only $1100{ }^{\circ} \mathrm{C}$ and cooling down to room temperature results in dense ceramic bodies, because no phase transition takes place in this temperature range (inset in Fig. 11).

The densities of ceramics after sintering at different temperatures (heating and cooling rate 10 $\mathrm{K} / \mathrm{min}$ ) are shown in Fig. 12. The bulk densities of the discs were determined by weighing and measuring dimensions. Green bodies of $\mathbf{3}$ require temperatures above $1200{ }^{\circ} \mathrm{C}$ to achieve comparable densities. Even sintering temperatures close to the melting point $\left(1280{ }^{\circ} \mathrm{C}\right.$ [9]) and a dwelling time of $10 \mathrm{~h}$ or longer leads to ceramics with a relative density of only $81 \%$. Ceramics sintered below $1250{ }^{\circ} \mathrm{C}$ consist of hexagonal $\mathrm{BaGeO}_{3}$ at room temperature. However, sintering temperatures $\geq 1250{ }^{\circ} \mathrm{C}$ and a dwelling time of more than $2 \mathrm{~h}$ hindered the reverse phase transition (orthorhombic $\rightarrow$ hexagonal) during the cooling stage (independent of the cooling rate) and results in ceramics consisting of orthorhombic $\mathrm{BaGeO}_{3}$. In contrast, green bodies of $\mathbf{2 a}$ show a better densification. The sintered bodies at $1000{ }^{\circ} \mathrm{C}$ (dwelling time $5 \mathrm{~h}$ ) have a relative density of $80 \%$. Up to a sintering temperature of $1150{ }^{\circ} \mathrm{C}$ ceramics with a relative density of $90 \%$ can be obtained.

Kher at al. [54] described an increase in the dielectric constant (relative permittivity, $\varepsilon_{\mathrm{r}}$ ) between about $20-30{ }^{\circ} \mathrm{C}$ for $\mathrm{BaGeO}_{3}$ prepared by the mixed-oxide method. Our dielectric measurements between $15-85^{\circ} \mathrm{C}$ on ceramic discs formed by conventional mixed-oxide method, as well as by the precursor method, do not show any increase in the dielectric constant $\left(\varepsilon_{\mathrm{r}} \approx 17\right)$. A possible reason for the anomalous behaviour reported by Kher et al. could have been the existence of impurities within the $\mathrm{BaGeO}_{3}$ powder, since the authors described the used $\mathrm{BaGeO}_{3}$ powder as a pinkish coloured powder.

\section{Conclusion}

The thermal decomposition of the $\left[\mathrm{Ba}\left(\mathrm{HOC}_{2} \mathrm{H}_{4} \mathrm{OH}\right)_{2} \mathrm{Ge}\left(\mathrm{OC}_{2} \mathrm{H}_{4} \mathrm{O}\right)_{3}\right](2)$ precursor in air proceeds to about $560{ }^{\circ} \mathrm{C}$ to yield a fine divided mixture of $\mathrm{BaCO}_{3}$ and $\mathrm{GeO}_{2}$, which subsequently reacts above $650{ }^{\circ} \mathrm{C}$ to afford $\mathrm{BaGeO}_{3}$ and in contrast to the conventional reaction between $\mathrm{BaCO}_{3}$ and $\mathrm{GeO}_{2}$, without any evidence for a prior formation of $\mathrm{Ba}_{2} \mathrm{GeO}_{4}$. Furthermore, orthorhombic $\mathrm{BaGeO}_{3}$ is observed below $900{ }^{\circ} \mathrm{C}$. Decomposition up to $1000{ }^{\circ} \mathrm{C}$ under argon or vacuum leads to the formation of $\mathrm{Ba}_{2} \mathrm{GeO}_{4}$. The thermolysis of the precursor in static air leads to preceramic powders with clearly better sintering activity than conventionally produced powders. For this reason, the 
resulting ceramics show at a sintering temperature of no more than $1150{ }^{\circ} \mathrm{C}$ a relative density of 90 $\%$.

\section{Acknowledgements}

The authors thank Dr. Th. Müller for XRD, dilatometric and thermoanalytic measurements and for his helpful discussions and also Dr. U. Straube (Department of Physics) for the dielectric investigations. We are also grateful to Ms. M. Kelly for reading the manuscript. Financial support by the State Saxony Anhalt (Cluster of Excellence "Nanostructured Materials") is gratefully acknowledged.

\section{References}

[1] K. Sugii, H. Iwasaki, S. Miyzawa, J. Cryst. Growth 10 (1971) 127-132

[2] W. Taylor, T. J. Hosea, Ferroelectrics 25 (1980) 503-505

[3] H. Iwasaki, K. Sugii, T. Yamada, N. Nizeki, Appl. Phys. Lett. 18 (1971) 444-445

[4] H. Koelmans, C. M. C Verhagen, J. Electrochem. Soc. 106(8) (1959) 677-682

[5] O. Yoshiharu, S. Yoshinori, T. Noboru, I. Isao, Germanates of divalent metals as powder for piezoelectric and dielectric ceramics. J.P. Patent No. 58199717 (1983)

[6] D. A. Payne, S. M. Park, Heterophasic Ceramic Composition. U.S. Patent No. 4,218,723 (1980)

[7] F. Liebau, Neues Jahrb. Mineral. 94 (1960) 1209-1222

[8] W. Hilmar, Acta Cryst. 15 (1962) 1101-1105

[9] J. P. Guha, J. Mater.Sci. 14 (1979) 1744-1748

[10] J. P. Guha, D. Kolar, A. Porenta, J. Thermal. Anal. 9 (1976) 37-41

[11] R. S. Roth, Am. Mineral. 40 (1955) 332

[12] O. Yamaguchi, M. Ki, T. Niimi, K. Shimizu, Polyhedron 2(11) (1983) 1213-1216

[13 ] L. Jäger, V. Lorenz, C. Wagner, T. Müller, H.-P. Abicht, Z. Kristallogr. 220 (2005) 183-187

[14] J. P. Guha, D. Kolar, J. Mater. Sci. 7 (1972) 1192-1196

[15] H. Thoms, M. Epple, A. Reller, Solid State Ionics 101-103 (1997) 79-84

[16] L. Erdey, F. Paulik, Acta Chim. Acad. Sci. Hung. 7 (1955) 27-44

[17] L. Erdey, F. Paulik, G. Svehla, G. Liptay, Z. Anal. Chem. 182 (1961) 329-335

[18] PDF 2 (International Centre for Diffraction Data, Pennsylvania) $\mathrm{BaCO}_{3}$ [5-378], $\mathrm{GeO}_{2}$ [83546 hexagonal $], \mathrm{BaGeO}_{3}$ [30-127 hexagonal $_{\text {i }}$ 37-137 orthorhombic $_{\text {, }} \mathrm{Ba}_{2} \mathrm{GeO}_{4}$ [39-1257], Ge [4-545 cubic]

[19] H. Kuno, A. Suzuki, Y. Sugimura, T. Yamaguchi, Funtai oyobi Funmatsu Yakin 14(1) (1967) 38-42 
[20 ] P. Royen, W. Forweg, Z. Anorg. Allg. Chem. 326(3-4) (1963) 113-126

[21] P. Royen, G. Wilhelmi, A. Kreher, Naturwissenschaften (1965) 390

[22] J. R. T. Johnson, I. Panas, Chem. Phys. 249 (1999) 273-303

[23] D. Dillomore, D. Nicholson, J. Chem. Soc. (1962) 960-965

[24] V. V Subba Rao, R. V. G. Rao, A. B. Biswas, J. Inorg. Nucl. Chem. 28 (1966) 415-420

[25] S. J. Gregg, J. Chem. Soc. (1953) 3940-3944

[26] G. Tammann, A. Sworykin, Z. Anorg. Allg. Chem. 176 (1928) 46-48

[27] G. F. Hüttig, Kolloid-Zeitschrift 98 (1942) 263-286

[28] G. F. Hüttig, Kolloid-Zeitschrift 99 (1942) 262-277

[29] H. Günzler, H. Böck, IR-Spektroskopie - Eine Einführung. Verlag Chemie GmbH, Weinberg/Germany, 1975, pp. 154-157

[30] P. Buckley, P.A. Giguere, Can. J. Chem. 45 (1967) 397-407

[31] D. Knetsch, W. L. Groeneveld, Inorg. Chim. Acta 7(1) (1973) 81-87

[32] H. Matsuura, T. Miyazawa, Bull. Chem. Soc. Japan 40 (1967) 85-94

[33] T. Takeuchi, M. Tasumi, Chem. Phys. 77 (1983) 21-34

[34] A. Miyake, J. Am. Chem. Soc. 82 (1960) 3040-3043

[35] D. K. Breitinger, T. Grützner, H. Wick, O. Schimmer, H. Eschelbach, J. Mol. Struct. 408/409 (1997) 383-386

[36] P. A. W. Dean, D. F. Evans, R. F. Philips, J. Chem. Soc.(A) (1969) 363-366

[37] P. Tarte, A.E. Ringwood, Nature 201(4921) (1964) 819

[38] H. Thoms, M. Epple, H. Viebrock, A. Reller, J. Mater. Chem. 5(4) (1995) 589-594

[39] H. Thoms, M. Epple, A. Reller, Thermochim. Acta 3375 (1997) 195-200

[40] B. D. Saksena, Trans. Faraday Soc. 57 (1961) 242-258

[41] A. N. Lazarev, T. F. Tenisheva, R. G. Grebenshchikov, Dokl. Akad. Nauk SSSR 140 (1961) 811-814

[42] I. S. Ignat’ev, A. N. Lazarev, Izv. Akad. Nauk, Neorg. Mater. 8(2) (1972) 280-284

[43] I. S. Ignat'ev, A. N. Lazarev, Izv. Akad. Nauk, Neorg. Mater. 8(2) (1972) 268-279

[44] J. Choisnet, A. Deschanvres, P. Tarte, Spectrochim. Acta 31A (1975) 1023-1034

[45] B. D. Begg, E. R. Vance, J. Nowotny, J. Am. Ceram. Soc. 77(12) (1994) 3186-3192

[46] R. C. Garvie, J. Phys. Chem. 69(4) (1965) 1238-1243

[47] E. S. Zhmud, A. B. Ivanova, A. A. Kotly, E. P. Ostapchenko, Z. Neorg. Khim. 7 (1962) 2581-2590

[48] F. Jasim, I. Jameel, Thermochim. Acta 115 (1987) 37-44

[49] P. Royen, W. Forwerg, Z. Anorg. Allg. Chem. 326(3-4) (1963) 113-126 
[50] W. Jander, J. Wuhrer, Z. Anorg. Allg. Chem. 226(3) (1936) 225-247

[51 ] T. Müller, H.-P. Abicht, cfi/Ber. DKG 77(9) (2000) E26-E31

[52 ] P. Duwez, F. Odell, J. Am. Ceram. Soc. 33(9) (1950) 274-283

[53] D. L. Porter, A. H. Heuer, J. Am. Ceram. Soc. 62(5-6) (1979) 298-305

[54] V. G. Kher, Ba. A. Patki, D. A. Deshpande, Curr. Sci. India 44(2) (1975) 46-47

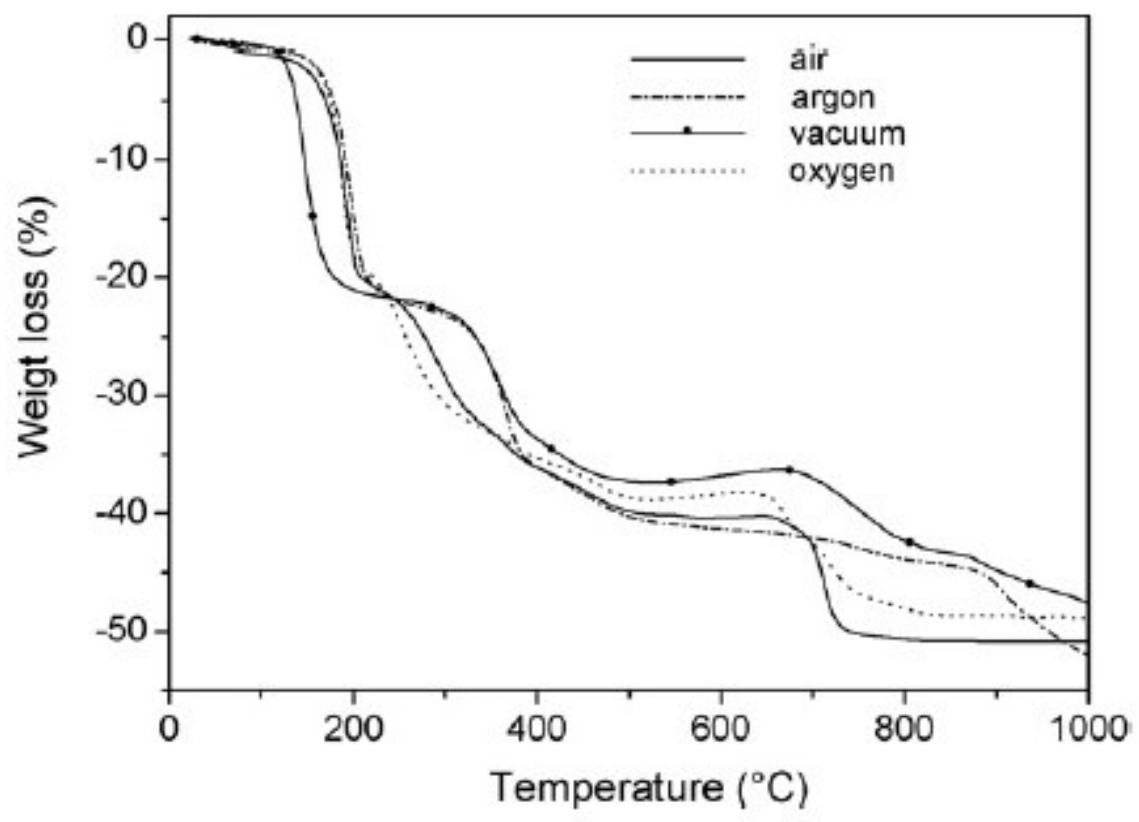

Fig. 1. TG curves of $\mathbf{2}$ in different atmospheres.

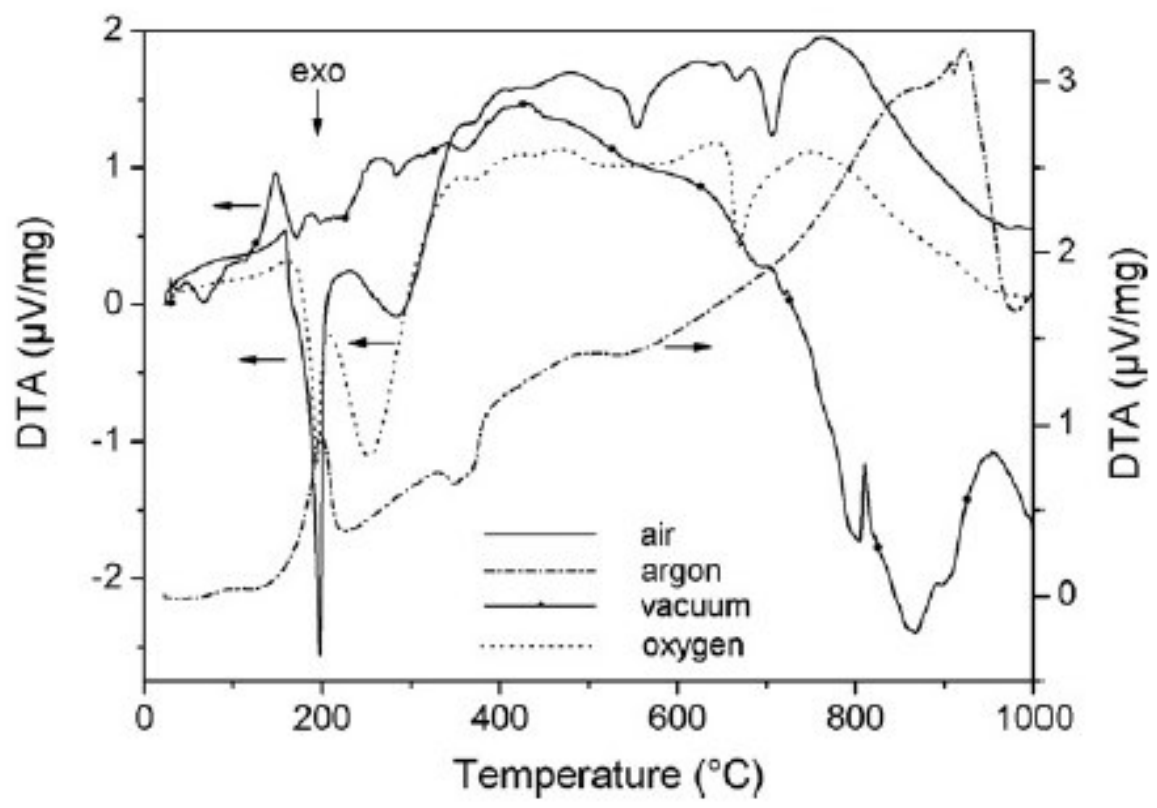

Fig. 2. DTA curves of $\mathbf{2}$ in different atmospheres. 


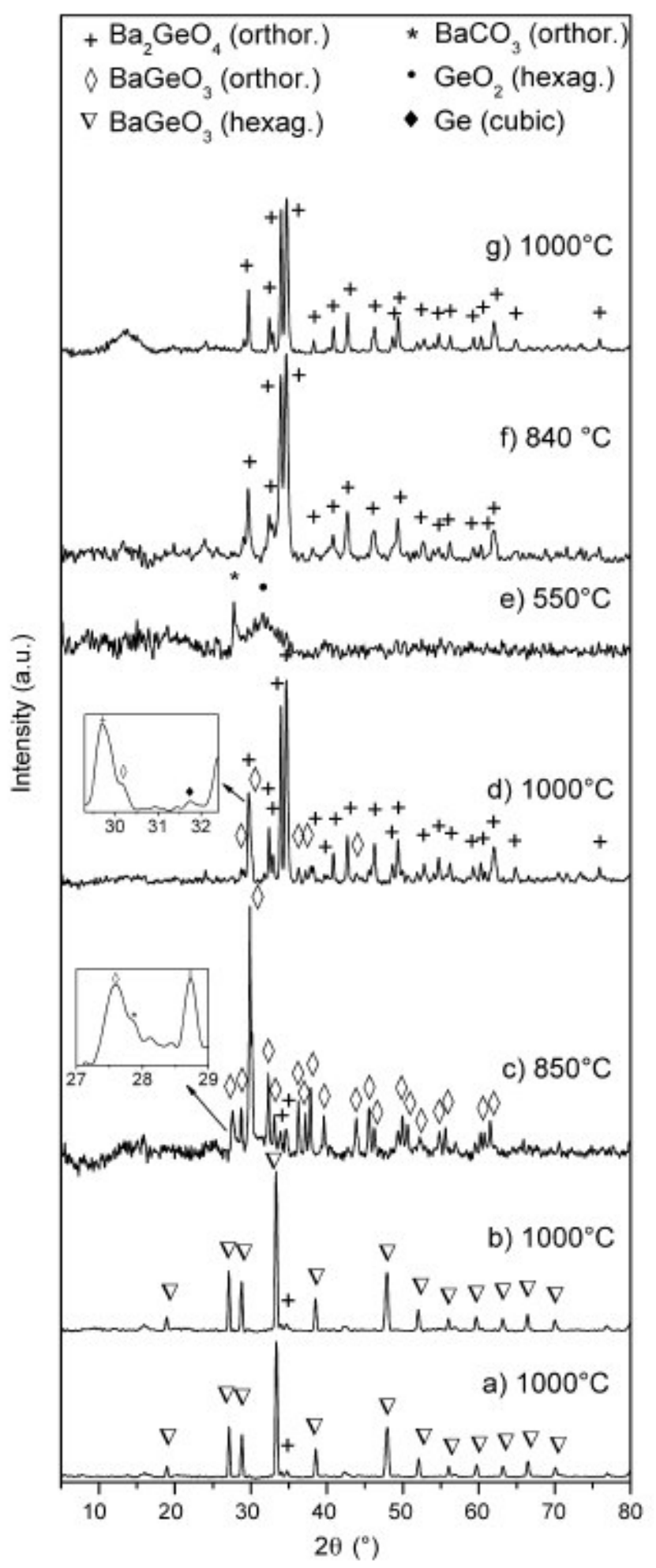

Fig. 3. XRD patterns of samples after TG/DTA investigations at the indicated temperatures in different atmospheres: (a) flowing air; (b) flowing oxygen; (c and d) flowing argon; (e-g) vacuum. The insets in (c) and (d) show an enlargement of the range between $2 \theta=27-32^{\circ}$ and $29-32^{\circ}$, respectively. 


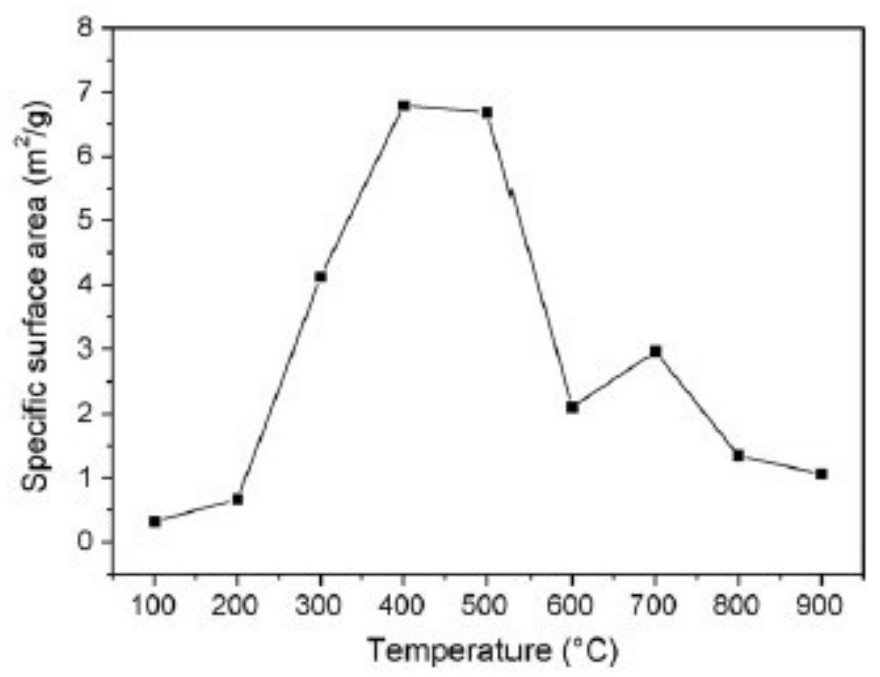

Fig. 4. Specific surface area vs. calcination temperature of $\mathbf{2}$ in static air (heating rate, $10 \mathrm{~K} / \mathrm{min}$; dwelling time, $1 \mathrm{~h}$ ). 

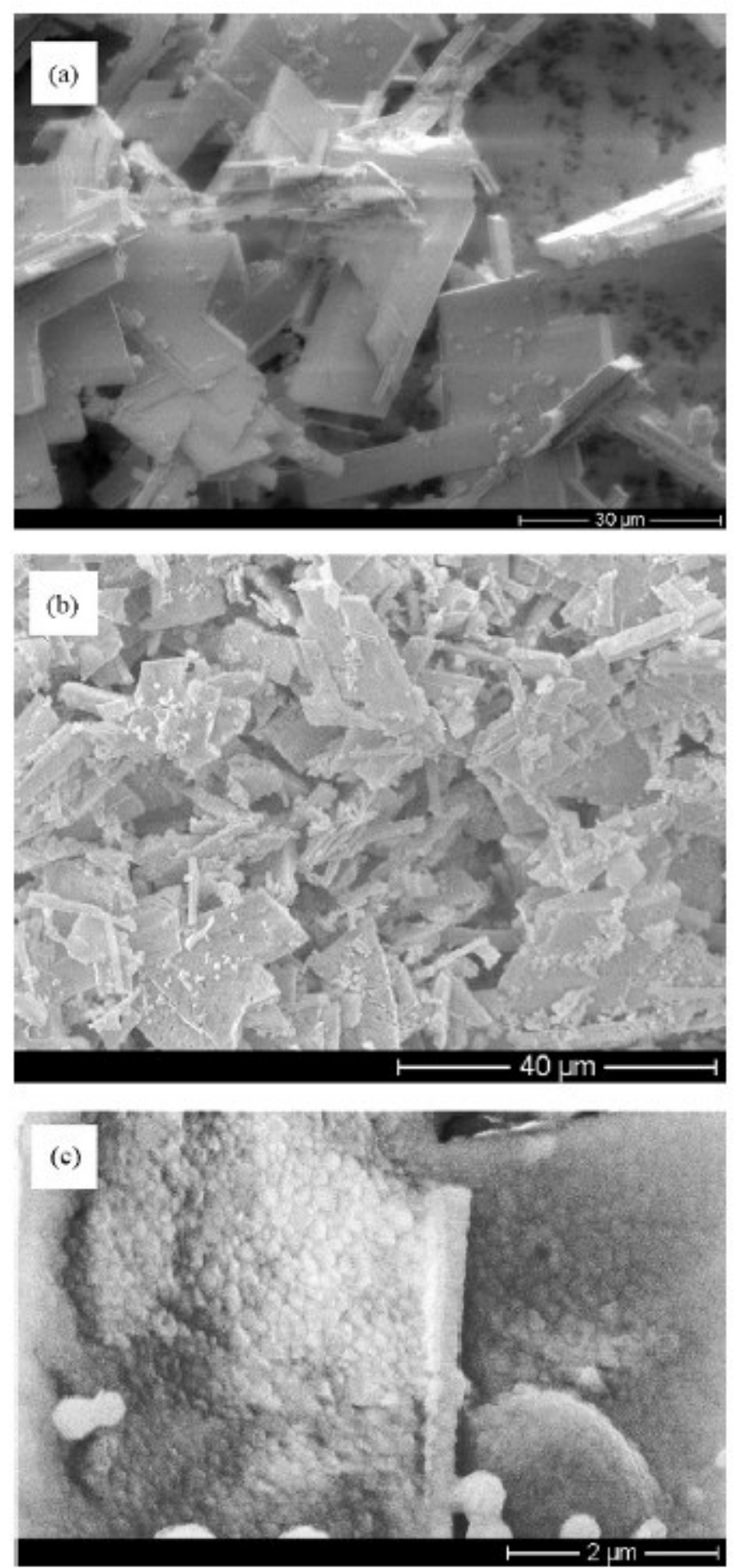

Fig. 5. SEM images of 2 (a) and calcined products (b) at $750^{\circ} \mathrm{C}(1 \mathrm{~h})$; (c) shows an enlargement of (a). 


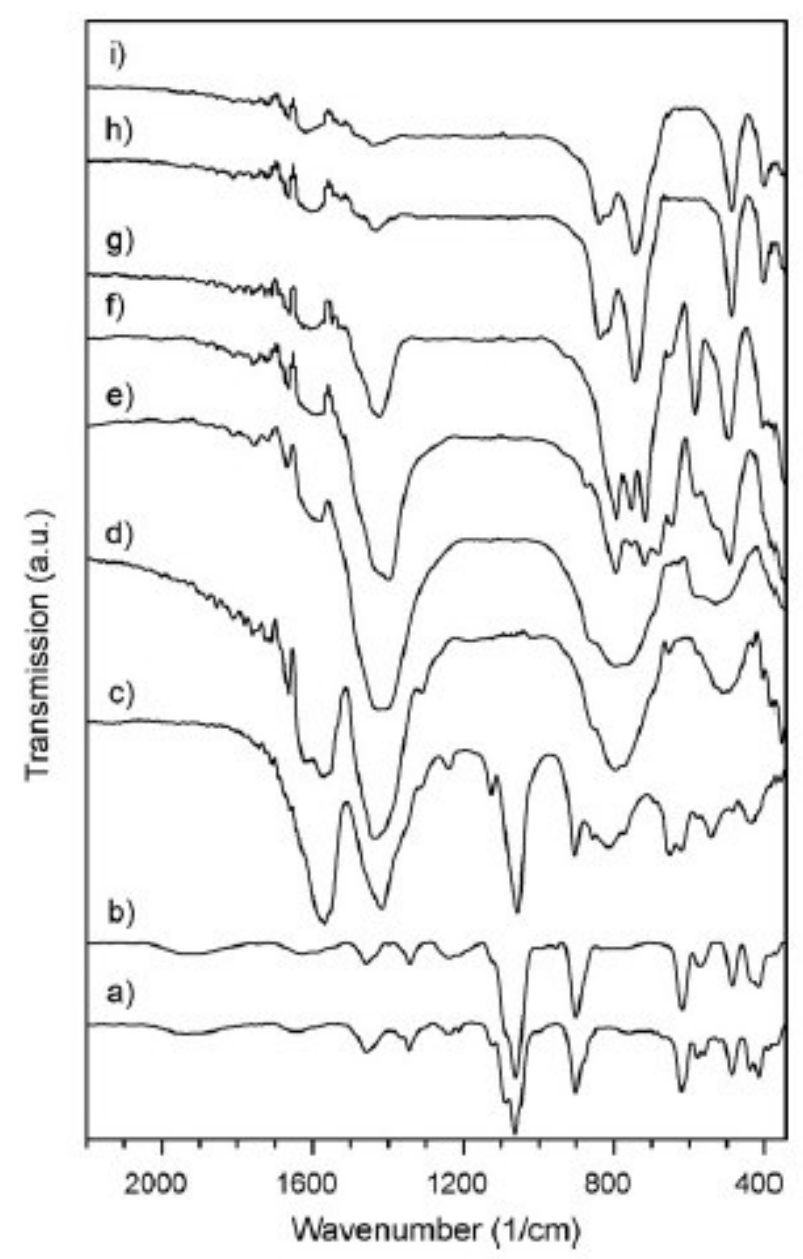

Fig. 6. IR spectra of 2 (a) and calcined products at various temperatures in static air (heating rate, $10 \mathrm{~K} / \mathrm{min}$; dwelling time, $1 \mathrm{~h}$ ): (b) $200^{\circ} \mathrm{C}$, (c) $300^{\circ} \mathrm{C}$, (d) $400^{\circ} \mathrm{C}$, (e) $600^{\circ} \mathrm{C}$, (f) $700^{\circ} \mathrm{C}$, (g) $800^{\circ} \mathrm{C}$, (h) $900^{\circ} \mathrm{C}$, and (i) $1000^{\circ} \mathrm{C}$. Spectra e-i show a weak broad band at about $1600-1670 \mathrm{~cm}^{-1}\left(\delta_{\mathrm{OH}}\right)$ due to water absorbed by the $\mathrm{KBr}$ powder and the samples. 


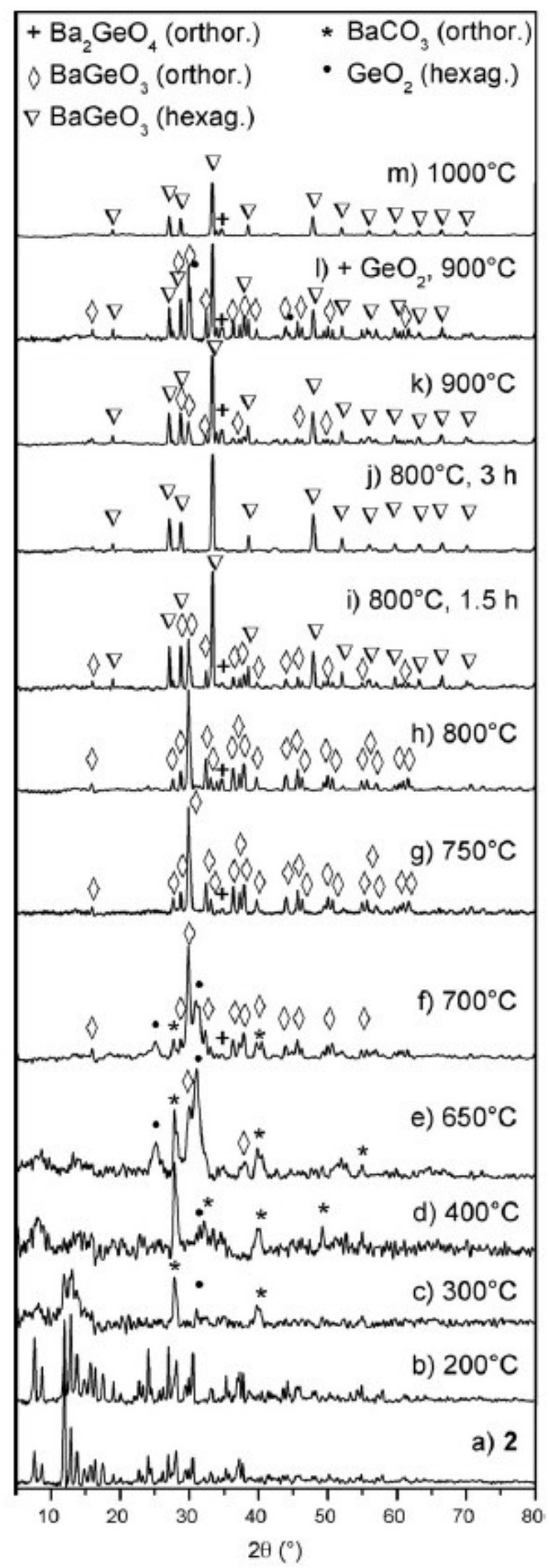

Fig. 7. XRD pattern of 2 (a) and calcined samples at the indicated temperatures in static air (heating rate, $10 \mathrm{~K} / \mathrm{min}$; dwelling time, $1 \mathrm{~h}$, except pattern (i) $1.5 \mathrm{~h}$ and (j) 3 h). (1) Mixture of 2 and $\mathrm{GeO}_{2}$ [83-543]. 


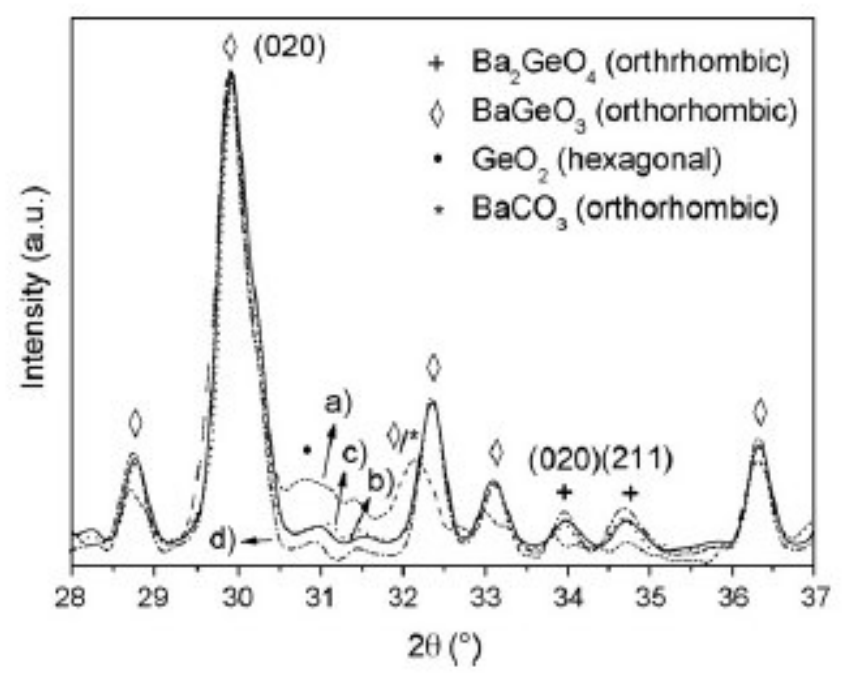

Fig. 8. Evolution of reflexions of $\mathrm{BaGeO}_{3}$ and $\mathrm{Ba}_{2} \mathrm{GeO}_{4}$ through the decomposition of 2 at $750^{\circ} \mathrm{C}$ in static air at different heating times. (a) $1 \mathrm{~min}$, (b) $30 \mathrm{~min}$, (c) $1 \mathrm{~h}$, and (d) $10 \mathrm{~h}$.

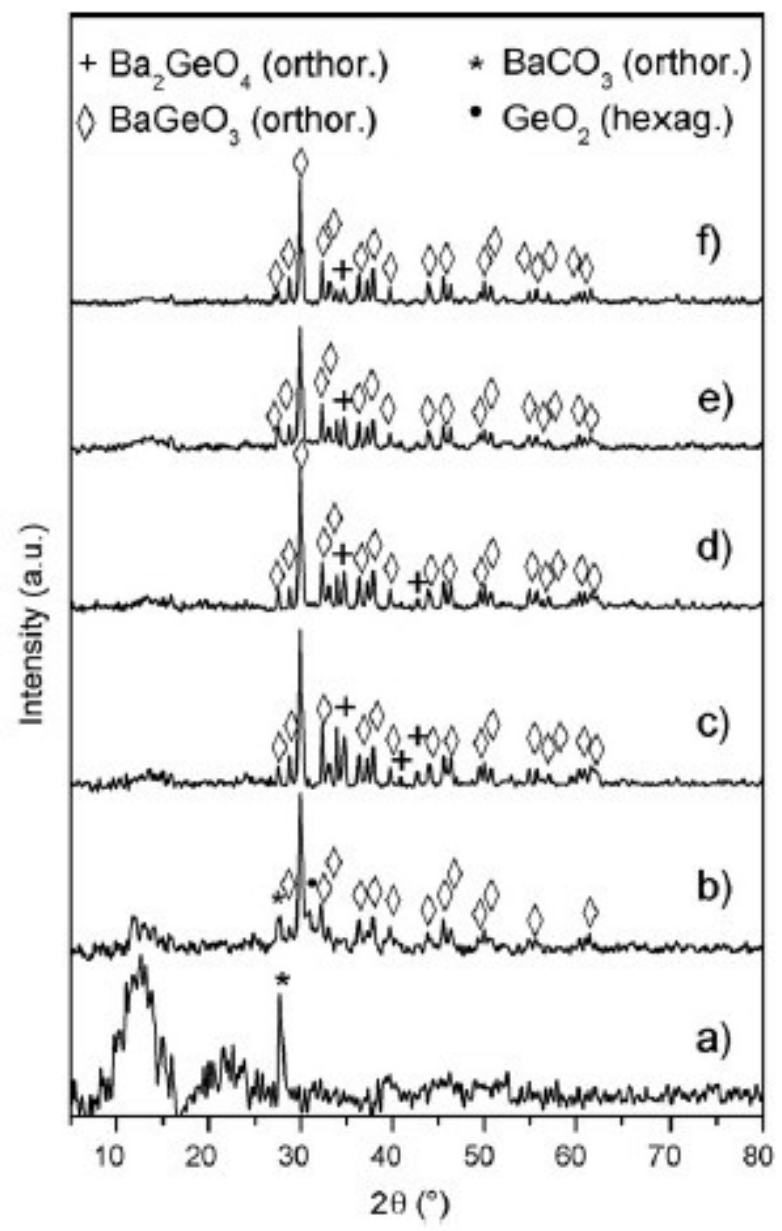

Fig. 9. XRD pattern of $\mathbf{2}$ calcined at various temperatures and dwelling times in flowing oxygen atmosphere (heating rate, $10 \mathrm{~K} / \mathrm{min}$ ): (a) $200^{\circ} \mathrm{C}, 1 \mathrm{~h}$, (b) $300^{\circ} \mathrm{C}$, $1 \mathrm{~min}$, (c) $300^{\circ} \mathrm{C}, 5 \mathrm{~min}$, (d) $300^{\circ} \mathrm{C}, 1 \mathrm{~h}$, (e) $400^{\circ} \mathrm{C}, 1 \mathrm{~h}$, and (f) $800^{\circ} \mathrm{C}, 1 \mathrm{~h}$. 


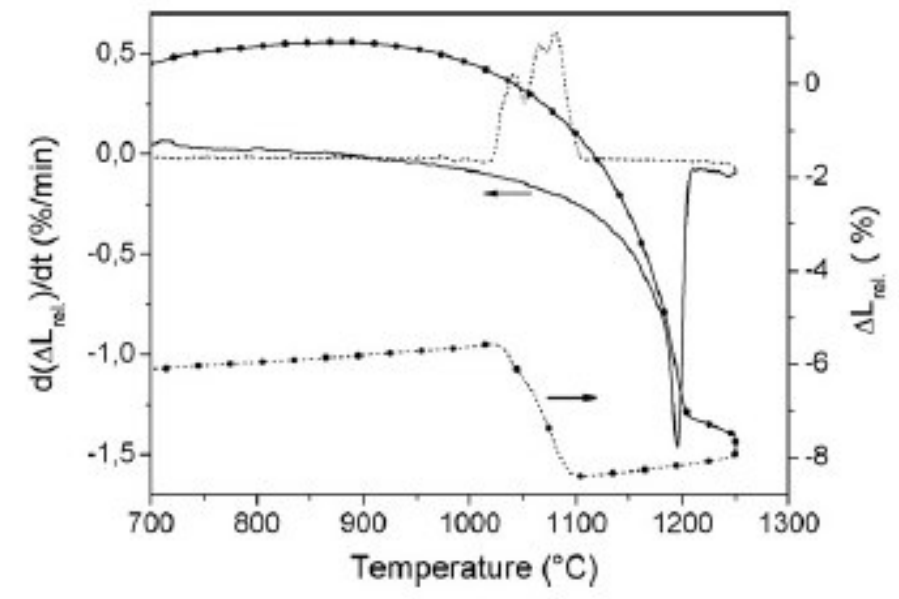

Fig. 10. The shrinkage behaviour up to $1250^{\circ} \mathrm{C}$ of a green compact of $\mathrm{BaGeO}_{3}$ (3). Solid lines represent the heating and dashed lines the cooling process.

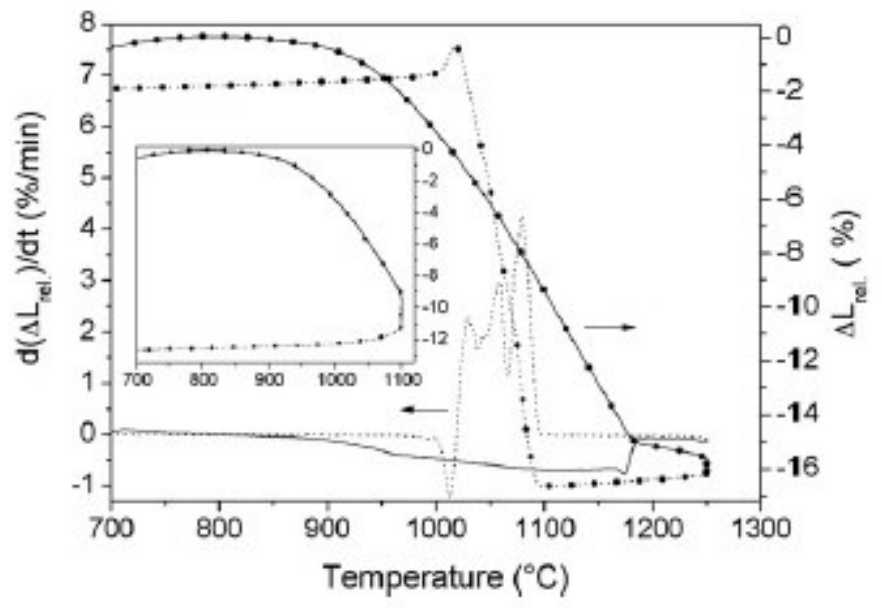

Fig. 11. The shrinkage behaviour up to $1250^{\circ} \mathrm{C}$ of a green compact of $\mathrm{BaGeO}_{3}$ (2a). The inset shows the dilatometric measurements up to a final temperature of $1100^{\circ} \mathrm{C}$. Solid lines represent the heating and dashed lines the cooling process.

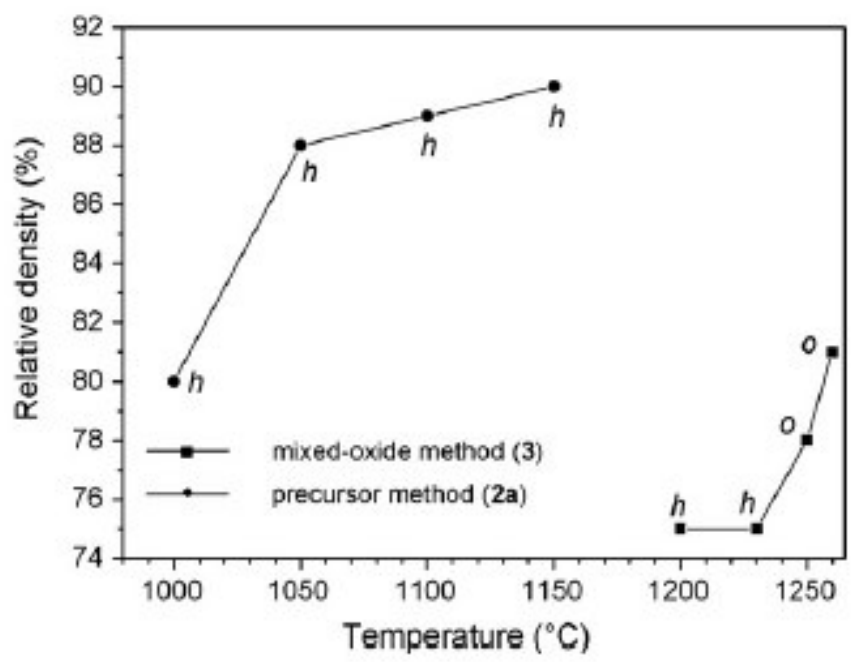

Fig. 12. Final density of sintered bodies depending on the sintering temperature. (a) Powder of $\mathbf{3}$ (sintering time $10 \mathrm{~h}$ ). (b) Powder of $\mathbf{2 a}$ (sintering time $5 \mathrm{~h}$ ). The relative density is related to the calculated X-ray density of the observed phase at room temperature; $\mathrm{h}=$ hexagonal phase, $\mathrm{o}=$ orthorhombic phase. 